\title{
1. The two sides of institutional innovation
}

\section{FROM THE BUREAUCRATIC STATE TO STATE INNOVATION}

Democratic innovation is a change in course in terms of classical democratic theory. Classical democratic theory did not value democracy for its capacity to innovate (Downs, 1957; Sartori, 1980; Schumpeter, 1942). Many classical scholars approached democracy formation only from the perspective of its relationship with the formation of political will. In the field of classical democratic theory, government has been seen more commonly as stable and predictable than as innovative (Weber, 1992, Vol. 2, p. 956).

Max Weber could be considered the most classical author on the subject of the predictability of different forms of government. According to his view, bureaucracy and predictable rules should form the basis of government, which should in turn make it possible for rational individuals to achieve their goals. Thus, for Weber, bureaucracy and government should be understood in terms of their capacity to produce 'precision, constancy, stringency and reliability of. . operations' (Weber, cited in Mommsen, 1989, pp. 13-14). Certainly, Weber was also aware of the tension between bureaucracy, government and political will, yet his view was that nothing could be done in modernity to alleviate this tension, which was a result of modernity itself (Schluchter, 1980, p. 117). Thus, innovation, for Weber, was not among the desirable characteristics of government. ${ }^{1}$

The New Institutionalism tradition has also dealt with the matter of innovation in government. New Institutionalism emerged with the aim of highlighting symbolic and normative systems that affect and constrain organizational choices (Powell, 2007, p.1). New Institutionalism considered cultural and normative systems as determining, facilitating or constraining choices taken by individuals within political institutions. The way the results of these 
constraints were perceived mirrored the way Weber saw political institutions, namely 'as stable patterns for sequences of activities that were routinely enacted' (Jepperson, 1991, pp. 144-5). Again, we see a tendency within political science to either oppose or ignore institutional innovation because of the fact that rules are required to generate predictability or constancy, which are central to the concept of institutionalization. However, not all New Institutionalist trends have adopted the same conception of the relationship between rules and predictability.

Hall and Taylor described two conceptions of rule behaviour within New Institutionalism and showed, particularly within historical and sociological institutionalism, that changes in actor and actor behaviour also produce changes at the institutional level: 'organizations often adopt new institutional practices, not because it advances means-ends efficiency of the organization but because it enhances the social legitimacy of the organization and its participants' (Hall and Taylor, 1996, p. 940). Thus, institutional life can be understood in two ways. According to one conception, the role of institutions is to give predictability to social actors. This is the conception of rational choice institutionalists (Przeworski, 1992, p.27; Tsebelis, 1994). According to a second conception, legitimacy issues need to be resolved by institutions, otherwise predictability becomes engrained and social actors lose the horizon their actions are aiming towards.

\section{THE CRITIQUE OF THE INSTITUTIONALIST VIEW ON INNOVATION}

Since the early 1980s, democracy evolved in the direction of a critique of the bureaucratic conception of government (Fischer, 2003, 2009). The critique of the Weberian view on innovation came from different theoretical perspectives. The first is a critique of technicians' and professionals' capacity to handle social reality without the input of social actors, a theory I will engage with in Chapter 2. The second is a critique of the Weberian framework. Habermas and J.L. Cohen and Arato were part of an attempt to provide a second view of Weber's concept of bureaucratization from a theoretical perspective. For them, the political system has to be open to innovation in practices brought by civil society actors to the public space.

For Habermas, the political system is not only an institution or a 
form of political organization; it is also a form of state and society interaction. In spite of Habermas's acceptance of the systemic view of administration, ${ }^{2}$ his work has opened the way for a broader conception of politics based on the concept of the public sphere (Habermas, 1989, 1996). The public sphere is the place where 'a public opinion generated more or less discursively in open controversies is certainly an empirical variable that can make a difference' (Habermas, 1989, p.47). Public sphere involves debates in spaces outside normal politics, spaces such as associations, churches and schools (J. Cohen, 2009). It also gathers claims in relation to the administrative authority. In this way, the public sphere theory is a point of departure for a dual conception of politics according to which civil society actors can act and influence the generation of new political ideas. The issue is how to transform these new political ideas into a new form of institutional organization.

In their seminal work on civil society, J.L. Cohen and Arato (1992; see also Emirbayer and Sheller, 1999; Glasius et al., 2004; Keane, 2003) help us to see how new drives within civil society associations may generate a non-bureaucratic view of the organization of political institutions. According to the authors, it is possible to maintain that 'modernized cultural forms set in motion discursive practices and expectations that cannot be kept away entirely from everyday life through selective institutionalization. As associations are transformed into bureaucratic organizations, new egalitarian and democratic associational forms tend to emerge' (Arato and J.L. Cohen, 1988 , p. 50). In short, the authors propose to analyse the processes of bureaucratization within a dual framework capable of pointing out new organizational potentials and breaking away from democratic elitism's one-dimensional analysis of bureaucratization.

The institutional duality of contemporary organizational structures opens up the possibility of new organizational forms as well as new institutional designs. Both social movements and voluntary associations can generate new organizational forms. Both draw on the ability of the communicative infrastructure of contemporary societies to respond to the bureaucratization of previous forms of interest aggregation and issue articulation (Przeworski, 2010). Thus, the analysis of political parties and parliaments upon which the democratic elitism based its conclusion that bureaucratization was inevitable need not be dismissed, but it needs to be strongly relativized (Evans, 1995; Fung and Wright, 2003). The available institutional 
forms do not exhaust the possibilities of social organization or the need for new policy organization (Baiocchi et al., 2011; Evans, 1995; Fraser, 2003). Thus, it is possible to propose more democratic, less bureaucratic institutions.

Solving the problems of bureaucratization requires providing a solution for the democratic debate that is different from those proposed by elitists (Dahl, 1971, 1990; Przeworski, 2010) and advocates of participatory democracy (Pateman, 1970, 2012). ${ }^{3}$ A dual conception of politics assumes the feasibility of a parallel but not alternative framework to the traditional mechanisms of interest aggregation. In such parallel spaces of discussion, new themes, new identities, and moral issues can be dealt with in ways that bypass the older forms of majority aggregation. The voluntary and democratic forms of action in this sphere renew the democratic potentials of the political system by facilitating discussion and decision within a local sphere of public participation that allows the aggregation of nonparticularistic interests.

By pointing out this new possibility, contemporary critical theory provides an alternative to the democratic elitist response to democracy. Instead of narrowing it to a procedure for resolving materially conflictual interests, critical theory points out the possibility of retrieving a parallel potential proper to associative life. A local public sphere can become the primary place for discussing identities, forming solidarities and discussing interests on a non-particularistic basis. Yet, the fact that such publics can develop an offensive capacity (Fraser, 2003) does not completely solve the problem of a Habermasian conception of an inherently defensive public sphere (Dryzek, 2000; Habermas, 1992) unless we suppose that the organizational drives generated by voluntary associations are automatically transferred to the political system, which would be a grave mistake. If, however, we assume that these drives may or may not be transferred and that there are different institutional methods of transferring them, we can see that in order for a public sphere to become offensive, it also needs to become deliberative.

There are two main reasons why Habermasian critical theory falls short of providing democratic theory with a non-elitist alternative: it limits the relationship between the public sphere and the political system to the transmission of influence and it dramatically reduces public deliberation by limiting it to law-making. Following systems theory (Luhmann, 1982; Parsons, 1951; Zolo, 1992), Habermas the- 
matizes the relationship between the public sphere and the political system in terms of the transfer of influence. According to this view:

[. . .]within the boundaries of the public sphere or at least of a liberal public sphere, actors can acquire only influence, not political power. The influence of a public opinion generated more or less discursively in open controversies is certainly an empirical variable that can make a difference. But public influence is transformed into administrative power only after it passes through the filters of institutionalized procedures of democratic opinion- and will-formation and enters through parliamentary debates into legitimate lawmaking. The informal flow of public opinion issues in beliefs that have been tested from the standpoint of the generalizability of interests. Not influence per se, but influence transformed into communicative power legitimates political decisions. (Habermas, 1996, p. 371)

Habermas's position on the role of the public sphere within democratic political systems is clear - it is not to produce decisions or deliberation, but through a symbolic form of communication that he calls influence to demand that the consensus that emerges at the level of public opinion be reflected in administrative decisions. This is where the theory shows its clear limits. For Habermas, modern citizens do not find a parallel forum for practising democracy or for expanding their participation in public policy. Thus, Habermasian theory falls short of providing an alternative way of reconnecting reason and will because, regardless of the rationality of the results of public debate, it is left to power-holders to decide whether to incorporate them into policy (Bohman, 1996). In this sense, Habermasian theory falls prey to the voice or exit dilemma. Alternative theories of public deliberation expand the Habermasian framework (Avritzer, 2002; Baiocchi et al., 2011; J. Cohen, 1997; J. Cohen and Rogers, 1995; Fischer, 2009; Fung and Wright, 2003; Warren, 2001).

\section{A SECOND SOURCE OF INNOVATION: PUBLIC DELIBERATION}

Habermas reduces the public sphere's deliberative aspect almost to a fiction - as if it were theoretically possible but empirically impossible, or least dangerous. A different response to the connection between the public sphere and the process of political deliberation should be constructed. This perspective should not be regarded as 
contradictory to discursive consensus-building; rather, it facilitates the formation of consensus on the policies to be implemented. According to this conception, 'a legitimate political system should foster deliberation and thus increase the chances of arriving at correct (or valid, fair or true) decisions' (Bohman, 1996, p. 6). The issue here is that without referring to institutional design, these new venues would never be constructed (Goodin and Dryzek, 2006; Smith, 2009).

Public debate is tied to a framework that 'both facilitates public discussion among equal citizens by providing favorable conditions for expression, association and discussion, and ties the authorization to exercise public power - and the exercise itself - to such a discussion by establishing a framework ensuring the responsiveness and the accountability of political power to it' (J. Cohen and Sabel, 1997). Public debate and political deliberation should not be separated, because both aim not only to create societal consensus but also to establish more accountability for the exercise of power. Thus, a stronger mechanism than influence is required to connect the public sphere to the political system.

J. Cohen $(1997,2009)$ provides us with a different possibility for connecting public debate and deliberation by stressing the institutional consequences of deliberation. He argues that the members of a democratic polity or public sphere should share 'a commitment to coordinating their activities within institutions that make deliberation possible' (1997, p. 72). This model provides a more effective way to bind deliberation and communication than Habermas's. Within a deliberative model, success and failure are different moments of the process of deliberation: in the first case because it is deliberation itself that provides the framework for a consensus agenda; in the second because deliberation might also play a role in avoiding the disruption of communication.

Fung and Wright (2003) take this debate further by giving a clearer institutional form to deliberative formats. For the authors, the phenomenon that has to be taken into account as a point of departure for reconstructing democratic vitality is to acknowledge:

[...]that the problem has more to do with the specific design of our institutions... If so, then a fundamental challenge for the Left is to develop transformative democratic strategies that can advance our traditional values - egalitarian social justice, individual liberty combined with popular control over collective decisions, community and solidarity, and 
the flourishing of individuals in ways which enable them to realize their potentials. (Fung and Wright, 2003, p.4)

Fung and Wright make an important point but also fall short of giving a comprehensive answer to the problem of innovation. The authors' important contribution is the criticism of conservative institutional politics in the issue of new institutional designs. They are less interested in debate issues such as normative values or commitments to democracy and more interested in approaching the translation of these issues for citizens' everyday lives. For them, the process of deepening democracy should focus on more concrete principles such as the focus on specific problems, the involvement of citizens in the decision-making process and the deliberative development of solutions to these problems (Fung and Wright, 2003, p. 15). Thus, their theory triggered a process of translation of deliberative democratic theory into principles of organization of the polity. This is the greatest merit of the book.

However, there is a second, more problematic issue that I will tackle here, which is whether or not these principles that were deduced from important experiences in the United States, Brazil and India can be extended to other settings or to other institutions in a non-problematic way. Because the authors narrowed down the analytical frameworks to one successful case for each of their examples of empowered participation, they could not find any variation in the context for the implementation of participatory institutions (J. Cohen and Rogers, 2003). Fung and Wright's approach to enabling conditions for the emergence of participatory institutions falls into the so-called cultural trap. Because their model is based on a heuristic assumption that successful designs may be carried out in different contexts, they suppose that the enabling conditions for participation are the same across different cultures. This critique would be key in the evaluation of the expansion of participatory budgeting or the co-optation of the Federal Electoral Institute (Instituto Federal Electoral - IFE; made in Chapters 3 and 4).

Fung and Wright's book and other works on deliberation have greatly contributed to a theory of participatory democracy based on deliberative designs. However, one issue in the Fung and Wright framework remains problematic, namely, the connection of these innovations to the political system. This problem, which had emerged in Habermas's theoretical framework during the early 1990s 
(Habermas, 1992; see also Bohman, 1996; Dryzek, 2000; Elstub et al., 2016; Hendricks, 2006), remained unresolved in the Fung and Wright model. It received an important solution in the deliberative systems framework.

\section{TOWARDS DELIBERATIVE AND PARTICIPATORY SYSTEMS}

The question of how to move from a participatory or deliberative experiment to a form of innovation that influences the political system has remained unresolved from the emergence of Habermas's work to Fung and Wright and other works on democracy (Avritzer, 2002; Baiocchi, 2005; Dagnino et al., 2007). Deliberative democracy and empowered participatory governance are a criticism of the aggregative view of democracy that dominated post-war democratic theory. They look for new institutional formats that can enhance practices that are very often devalued by the political system in contemporary democracies (Avritzer, 2002, p. 11; 2009, p. 8; Baiocchi et al., 2011, pp. 10-11; Fung and Wright, 2003, p. 16).

Parkinson and Mansbridge present the idea of deliberative systems as a way to overcome the current stalemate in both deliberative theory and deliberative practice, a stalemate that makes the connection between deliberation and the political system problematic (Dryzek, 2001; Hendricks, 2006; Parkinson, 2006). As a solution to this problem, they propose a deliberative system as 'a set of distinguishable, differentiated, but to some degree interdependent parts, often with distributed functions and a division of labour, connected in such a way as to form a complex whole' (Parkinson and Mansbridge, 2012 , p. 6). This definition is the starting point for thinking about deliberative systems in North Atlantic democratic theory - a form of integration through everyday talk and the formation of mini-publics (Parkinson and Mansbridge, 2012).

The theory of deliberative systems resides at the intersection of talk-based mini-publics and parliament. Many authors have approached the idea of mini-publics. According to Goodin and Dryzek, mini-publics 'are designed to be groups small enough to be genuinely deliberative, and representative enough to be genuinely democratic (though rarely will they meet standards of statistical representativeness, and they are never representative in the electoral 
sense)' (Goodin and Dryzek, 2006, p.220). Though Goodin and Dryzek did not emphasize the semi- or quasi-institutional form of mini-publics, other authors such as Archon Fung and Graham Smith have done so. Fung points out that mini-publics may acquire a semi-institutional form as they fulfil the promises of inclusiveness and democratic equality of deliberative democracy (Fung and Wright, 2003, pp. 34 42; Smith, 2009, p. 109). In his excellent piece on institutional designs for mini-publics, Fung highlights the existence of two different publics that can be participatory in terms of advising or in terms of problem-solving. For him, 'this type [of public] envisions a continuous and symbiotic relationship between the state and the public sphere aiming at solving particular collective problems' (Fung and Wright, 2003, p. 25). Thus, Fung builds upon the work of Dryzek and Goodin in the sense that he acknowledges the interaction between the state and society as a dimension of the institutional design of some mini-publics, and particularly of the ones he calls 'participatory democratic governance'.

The best mini-publics approach is the one adopted by Smith. Smith deals with the artificial dimension of mini-publics by making clear that 'participants are selected using random sampling techniques', but he also acknowledges that mini-publics are a type of assembly, put together by random selection (Smith, 2009). In this sense, he both draws from and goes beyond the existing literature on mini-publics by recognizing assemblies as an institutional format that differs from mini-publics. In my opinion, a number of points have been overlooked in the debate on mini-publics, and analysing them in depth may help us to better evaluate democratic innovation in Brazil. ${ }^{4}$

The first point overlooked is the artificiality of the recruitment process and the institutional detachment of the mini-public design from the political system (Sintomer, 2010; Smith, 2009). Many authors have argued that the key element in the effectiveness of mini-publics is the randomness of the selection process (Sintomer, 2010, pp. 480-82; Smith, 2009, p. 73). The most important democratic element of the lot is political equality generated by the common capacity of a deliberating citizen. The second most important element is a pragmatic epistemology that allows citizens to construct their own view of a public policy they had no role in designing (Ramos, 2013). Other authors, and Sintomer in particular, see the mini-public as a second best to broad publics. However, the 
theory of deliberative systems fails to recognize that mini-publics remain secluded from the real institutions and fail to influence real politics. ${ }^{5}$ In this sense, following a mini-public exercise there is always some doubt about how the outcome of the exercise may become influential within the broader political system. Thus, it remains doubtful whether democratic mini-publics can become intertwined with broader political institutions, unless we assume that talk-based politics are sufficient to establish this connection (Parkinson and Mansbridge, 2012).

A second, often overlooked issue is how mini-public theoreticians conceive of the problem of inclusion. Inclusion in politics may assume different meanings: social inclusion of the poor, cultural inclusion of marginalized groups (Fraser, 2003), discursive inclusion (Habermas, 1994) or inclusion through policy deliberation (Fischer, 2009). From the perspective of mini-publics, inclusion refers to discursive integration. Deliberative democracy has often understood inclusion as the discursive or thematic inclusion of ideas and themes that were originally excluded from the public sphere (Dryzek, 2001). The debate on mini-publics has often followed the same reasoning, establishing the lot as a good way of decentring deliberation from already established interests (Sintomer, 2010). Goodin and Dryzek argue that 'some claim' of 'representativeness' is enough to establish a mini-public:

By 'some claim,' we do not mean statistical representativeness - which only one design, the deliberative poll, explicitly asserts. Nor do we mean electoral representation. All 'some claim to representativeness' need mean is that the diversity of social characteristics and plurality of initial points of view in the larger society are substantially present in the deliberating mini-public. (Goodin and Dryzek, 2006, p. 221)

In my view, political inclusion needs to go beyond this to attempt to effectively include not only ideas but also those who are socially and culturally excluded from the polity. It is interesting to note that these issues affect a theory on deliberative systems.

In my opinion, these authors fail to show how these two elements of politics - everyday talk and mini-publics - are integrated into the political system. Thus, there is an automatic assumption that if talk is successful, it will positively impact the political system. However, there is no guarantee that this will happen, and in this sense we are still within the Habermasian trap. As Pateman has recently 
remarked, mini-publics 'are not integrated into the overall system of representative government or democratic institutions, nor do they become part of the regular political cycle in the life of a community' (Pateman, 2012, p. 10).

Meanwhile, participatory systems and participatory accountability as important innovations from the South, have remained undertheorized. Brazil, Bolivia, Mexico and Argentina's participatory systems share a number of key characteristics. First, they emerged at the grassroots level with a strong presence of institutionalized local assemblies, small public or participatory accountability institutions. These assemblies have roots in different moments of these countries' democratization process: local assemblies in Brazil, instituciones ciudadanas (citizen institutions) in México, comités de vigilancia (monitoring committees) in Bolivia, asambleas barriales (neighbourhood assemblies) in Argentina, and are results of the process of democratization or of state and society conflicts in the aftermath of democratization.

With the evolution of democratization, as I will show in Chapter 3 , new institutionalized forms of participation such as participatory budgeting emerged. These new forms of participation are institutional because they are triggered by decisions made by elected officials, for example in the case of participatory budgeting, where the mayor of Porto Alegre took the initiative of proposing its implementation and the city organized the assemblies (Baiocchi, 2005, p. 56) or in the case of the Ley de Participación Popular (Popular Participation Law - LPP) in Bolivia, it has been approved at the national assembly. They are also much broader in the sense that their success is related to the number of participants they are able to engage, although quality may also play a role. ${ }^{6}$

A second key characteristic of participatory systems in Latin America is how they connect participation with administration and representation. In Brazil, participation has been linked with administration since the introduction of participatory budgeting (Avritzer, 2002). Participatory budgeting decisions become mandatory after their approval at the participatory budgeting council, and the administration of Porto Alegre has established new administrative institutions such as the Gabinete de Planejamento (Planning Office GAPLAN) to incorporate these decisions into the government's proposed budget (Abers, 2000). We see similar tendencies in Bolivia, Argentina and Mexico. In Bolivia the LPP has decentralized 20 per 
cent of the budget to the local level and institutionalized almost 16 000 civil society institutions and social movement organizations (organizaciones territoriales de base - OTBs) to establish community priorities. Its most important achievement was the creation of administrative references for the rural communities.

The experience of participatory budgeting in Rosário, Argentina, shows the integration of asambleas barriales into the institutionalized logic. Last but not least, the most intense democratic moment of Mexican democratization also involved the creation of new institutions such as the Federal Institute for Access to Public Information (Instituto Federal de Accesso a la Información Pública - IFAI). Thus, it is possible to state that all Latin American cases of participation involved the emergence of institutions with strong participatory orientation that were part of an attempt to craft a participatory system.

To summarize, we can say that a participatory system centres on the idea of linking different participatory and deliberative processes together and linking those processes to the political system and the state. These two links are responsible for the integration between participation and representation. This integration must take place via institutional mechanisms because it is politically naive to assume that all or most results of talk-based deliberation have the potential to make their way into the political system. Although they may or may not become a part of the political system, they stand their best chance through the institutionalization of political participation, although often this form of institutionalization becomes a very contentious issue, as it was in Brazil in 2014 or Mexico in 2007-08. These characteristics are not exclusive to the Brazilian experience of participatory budgeting but are also shared by successful experiences of participation in other South American countries, as the experience of participatory budgeting in Rosário shows.

\section{POLITICAL INNOVATION AND CONTENTION IN NEW DEMOCRACIES}

The debate on political innovation or democratic deliberation poses two issues, one of them grossly overlooked by deliberative democrats. The first is how to make innovations influence the political system. It is possible that this remains the key issue in critical democratic 
theory. It is clear that democratic innovation may foster citizenship and participation. It is also clear that citizens learn a new conception of democracy and start to practise it, creating important new inputs to the political system. However, we cannot underestimate the difficulties posed by the political system to changes brought by democratic innovation. There have been examples of this difficulty to expand participation in Mexico, Brazil and Argentina. In Mexico, the short-lived experience of ciudadanización (citizenization - citizen involvement) was thwarted by the events following the 2006 presidential elections. The IFE was submitted to a control body whose link with Congress weakened the Institute. In the Brazilian case, Congress was completely hegemonized (dominated by conservative sectors) through an illegal process by which 19 companies financed more than 50 per cent of the campaigns (Mancuso, 2015). This new conservative majority posed itself against the expansion of social participation in Brazil through its proposal of Law Decree No. 8243, which created the National Policy on Social Participation (Zanandrez, 2016). In Argentina the Kirchners ${ }^{7}$ were able to control the government of the province of Buenos Aires and effectively shut down participatory budgeting in the city. Thus, the issue of how to renew practices through the strengthening of a bottom-up process of political innovation remains unanswered. On the one hand, institutional innovation remains the best bet on how to improve the quality of the political system (Morlino, 2012). On the other, it is very clear that innovation does not transmit itself automatically to the political system. I will go even further and point out that with the exception of token participation, most of the political system is closed to political innovation or accepts only token or symbolic aspects of important political innovations such as participatory budgeting and deliberative mini-publics.

The second issue is the expansion of innovation. On the one hand, there is nothing wrong with Fung and Wright's idea that successful innovation should be reproduced. However, two important limits should be kept in mind in the process of expanding innovation. The first is cultural and contextual, and I have written about it in earlier works (see, for example, Avritzer, 2009). I return in the book to this argument showing that councils, local assemblies and ciudadanización are all based on important local traditions that in certain cases go back to the colonial period (Forment, 2009; Lockhart and Schwartz, 1983; Van Cott, 2008). 
The second is related to different actions of the political system, because it is impossible to broadly expand innovation without a political actor willing to do so. I have in mind here the process of expansion of participatory budgeting in Brazil, which has been carried out mainly by the Workers' Party (Partido dos Trabalhadores - PT) (Avritzer and Wampler, 2008) or the supra-party support for the LPP in Bolivia. It is important to remember that successful expansion is also possible, as experiences of participatory budgeting in Recife and Canoas, Brazil, show. Successful experiences of participatory budgeting have occurred outside Brazil as well, such as in Rosário, Argentina (Annunziata, 2011; Ford, 2007). Mexico also shows a second possibility, which is the expansion of the participatory or democratic accountability design to other areas of government, as the Access to Information Law (Ley Federal de Transparencia y Acceso a la Información Pública Gubernamenta) has done. Yet, the issue is how fully actors engage in democratizating democracy and carrying out distributive policies and there are more examples of political actors disengaging in the expansion of these designs than engaging, as I will show in Chapters 3 and 4.

Even in successful cases of innovation we see different processes of reversal of implementation of participatory designs in Mexico, Brazil and Argentina. The IFE in Mexico is a good example in this regard. The IFE has been one of the stars of citizenship engagement and innovation during Mexico's democratization (Aguayo, 1995; Avritzer, 2002). New monitoring practices emerged through citizenship participation and allowed clean elections in Mexico from 1996 on (Cantun, 2002; Hevia and Isunza, 2010). However, innovation success is often accompanied by problems. In the case of the IFE, a deal among the most important political parties in the aftermath of charges of election fraud allowed the disempowerment of citizenship at the IFE. There are similar cases in Brazil and Argentina. In Argentina, participatory budgeting in Buenos Aires has been involved in a network of empowerment and disempowerment that in the end led to its discontinuation (Rodgers, 2010). In Brazil, the disassembling of participatory budgeting experiences even under PT administration is very common.

The political system is the key element in the expansion or contraction of democratic innovations. They move forward in the cases in which the political system engages in the expansion of innovation or at least does not block them, as has been the case in Sánchez de 
Table 1.1 The dynamics of participatory innovation

\begin{tabular}{|c|c|c|c|}
\hline Country & $\begin{array}{l}\text { Type of New } \\
\text { Democratic } \\
\text { Institutions Created }\end{array}$ & $\begin{array}{l}\text { Reasons for } \\
\text { Successful } \\
\text { Implementation }\end{array}$ & $\begin{array}{l}\text { Actors Who } \\
\text { Limited or } \\
\text { Attacked New } \\
\text { Institutions }\end{array}$ \\
\hline Brazil & $\begin{array}{l}\text { Participatory } \\
\text { budgeting and policy } \\
\text { councils }\end{array}$ & $\begin{array}{l}\text { Support of the PT } \\
\text { and civil society } \\
\text { actors }\end{array}$ & $\begin{array}{l}\text { Participation } \\
\text { received supra- } \\
\text { party support until } \\
2014\end{array}$ \\
\hline Mexico & IFE and the IFAI & $\begin{array}{l}\text { Support of civil } \\
\text { society actors and } \\
\text { acceptance by } \\
\text { PRI actors after } \\
\text { long process of } \\
\text { negotiation }\end{array}$ & $\begin{array}{l}\text { IFE received } \\
\text { supra-party } \\
\text { support until } \\
\text { 2006; all parties } \\
\text { contributed to the } \\
\text { disempowerment } \\
\text { of the IFE }\end{array}$ \\
\hline Argentina & $\begin{array}{l}\text { Participatory } \\
\text { budgeting }\end{array}$ & $\begin{array}{l}\text { Support of civil } \\
\text { society and } \\
\text { political actors in } \\
\text { the case of Rosário }\end{array}$ & $\begin{array}{l}\text { Kirchneristas tried } \\
\text { to derail PB }\end{array}$ \\
\hline Bolivia & $\begin{array}{l}\text { Ley de Participación } \\
\text { Popular and comités } \\
\text { de vigilancia }\end{array}$ & $\begin{array}{l}\text { Broad support of } \\
\text { political actors }\end{array}$ & $\begin{array}{l}\text { MAS politicized } \\
\text { comités de } \\
\text { vigilância }\end{array}$ \\
\hline
\end{tabular}

Note: $\quad$ IFE $=$ Federal Electoral Insitute IFAI $=$ Federal Institute for Access to Public Information; PT = Workers' Party; PRI = Institutional Revolutionary Party; $\mathrm{PB}=$ participatory budgeting; MAS $=$ Movement for Socialism.

Losada's ${ }^{8}$ support for the LPP or President Vicente Fox Quesada's ${ }^{9}$ support for the Access to Information Law. However, the clearest case of support for participation is Brazil during the National Constituent Assembly. These are the successful cases that do not preclude important reversal because democratic innovation very often remains contentious within the political actors who have sponsored it in the first place. Table 1.1 summarizes the different paths of expansion and retraction of innovation.

However, the most acute danger innovation faces is when corporations pick up the discourse of institutional or democratic innovation. This happened with the Ministério Público in Brazil. The effects of this reform have come in fits and starts. The 1988 Constitution 
established in Article 127 an independent Public Prosecutor's Office, the Ministério Público. The idea of a Ministério Público was an innovation in relation to the previously existing institutional format in which the executive branch in Brazil controlled the Declaration of Unconstitutionality at the same time that there was a very low level of enforcement in relation to human rights and the environment (Avritzer and Marona, 2016). In addition to that, corruption has been rampant. The institutional design of the Ministério Público made it both a bureaucratic organization and an autonomous agency. As a bureaucratic organization, the Ministério Público draws on a strong principle of legality that it tries to impose on every organization or association it controls or audits (Oliveira et al., 2015). As an autonomous agency, the Ministério Público draws on a principle of complete autonomy that it justifies as leading to obeisance only to a citizenship principle. In Chapter 5 I will show how the Ministério Público became a very dangerous organization, with anti-democratic behaviour by its members drawing selectively on the principle of autonomy.

Thus, an initial theoretical position on democratic innovation is clear. We understand innovation as the changes in design that support the expansion of citizenship or the integration of citizenship claims into the political system. There have been historically different waves of integration of political participation in the state. We are currently passing through a long wave of democratic innovation that poses real possibilities for the expansion and the improvement of the quality of democracy. This is not a first wave of innovation in world democracies. In the United States in the early twentieth century, innovation was linked to progressivism and the introduction of democratic mechanisms such as the referendum and the recall in the American West (Fischer, 2003; Pierson, 2004). This first wave of innovation came to a close after World War II. The current wave of democratic innovation is part of the third wave of democratization and in this regard it has one major change from previous waves; it has a global dimension and includes countries in the South, particularly the new Latin American democracies. It is the deliberative and participatory practices of these new democracies that this book will address.

This book seeks to establish a double dialogue with deliberative democrats in their approach on the democratization of democracy (Cohen, 2010; Dryzek, 2006; Fung, 2007; Parkinson and Mansbridge, 
2012; B. Santos, 2002; Sintomer et al., 2008). It seeks a dialogue based on experiences that may further enlighten the theory through the incorporation of new experiences of participation. It seeks to throw light upon differences in design and to trigger a process of comparative analysis within this theoretical field. Second, the book also intends to show limits to the implementation of new designs linked to the specific interaction with the political system. Thus, the Latin American cases play the role of an additional case in the theory of democratic and participatory innovation because they bring forth experiences that bind the political system within democratic innovation more closely. At the same time, these new cases of innovation are also vulnerable, as I will show, to the derailment of innovation by the same political system. The book will try to present a balance of the new Latin American experiences in the hope of providing new insights into their mechanisms and on how they help or hinder democratic deepening, in the hope of making these experiences more widely known and singling out their contributions to democratic deepening in the region.

\section{NOTES}

1. It should be noted that Weber proposed the 'charismatic leader' as a solution to this problem. The charismatic leader, according to Mommsen, is an antinomy in Weberian thought. On the one hand, Weber understood democracy as generating the free and self-determined individual. On the other, Weber perceived democratic leadership as a variant of charismatic leadership, whereby the choice of a leader is legitimized only in form but not in substance (see Mommsen, 1989, p. 33; see also Breiner, 1996, p. 139).

2. Many people criticize Habermas in this regard, starting with his long-time interlocutor in the United States, Thomas McCarthy. For them, Habermas conceded too much to a traditional and systemic view on politics (McCarthy, 1981). Fischer (2009, p. 31) criticizes Habermas from the perspective of the double side of technological complexity.

3. It is worth pointing out that in an excellent review article published recently, Pateman (2012) heavily revised her framework proposed in Pateman (1970) and pointed towards a tension between participation and deliberation.

4. Some of these points emerged after a very enjoyable discussion with Graham Smith in London. I thank him for sharing his thoughts on mini-publics with me.

5. Simone Chambers (2006) has discussed this dilemma, albeit from a very different perspective. For her, deliberative democracy chose to substitute mass publics for mini-publics, opting for the quality of small public debate instead of mass democracy.

6. Baierle (1998) analysed local assemblies in terms of which actors have the most voice in the process. He showed that the use of voice was fairly distributed in 
participatory budgeting, with poor social actors making frequent use of the floor.

7. Cristina Fernández de Kirchner became the first female elected president of Argentina, 2007-15. She succeeded her husband, Néstor Kirchner, who had served as president from 2003 to 2007.

8. President of Bolivia 1993-97 and 2002-2003.

9. President of Mexico, 2000-06. 